\title{
Comparison of changes in land use and land cover in China and the USA over the past 300 years
}

\author{
HE Fanneng ${ }^{1}$, LI Meijiao ${ }^{1,2}$, LI Shicheng $^{1,2}$, XIAO Ran $^{1,2}$ \\ 1. Key Laboratory of Land Surface Pattern and Simulation, Institute of Geographic Sciences and Natural Re- \\ sources Research, CAS, Beijing 100101, China; \\ 2. University of Chinese Academy of Sciences, Beijing 100049, China
}

\begin{abstract}
Comparative studies of changes in land use and land cover between different countries over a long time-scale are helpful in understanding the processes and driving forces of these changes in different situations. We compared and analyzed the temporal and spatial characteristics of cropland, forest and grassland between China's mainland and the conterminous USA over the past 300 years. We found that, over the past 300 years, the area of cropland showed an overall increasing trend both in China and in the USA. In China, the area of cropland increased by about $79.46 \times 10^{4} \mathrm{~km}^{2}$ from 1661 to the $1980 \mathrm{~s}$, and the per capita cropland decreased from $0.37 \times 10^{4} \mathrm{~m}^{2}$ in 1685 to $0.10 \times 10^{4} \mathrm{~m}^{2}$ in 2000 . For the USA, the area of cropland increased by $190.87 \times 10^{4} \mathrm{~km}^{2}$ between 1700 and 1950 . The per capita cropland area of each time slice for the past 300 years was greater than $0.60 \times 10^{4} \mathrm{~m}^{2}$ and the maximum value was $2.01 \times 10^{4} \mathrm{~m}^{2}$ in 1890 . As a result of the expansion in land reclamation, the forest and grassland areas of the USA have decreased by about $136.98 \times 10^{4} \mathrm{~km}^{2}$ and $136.98 \times 10^{4}$ $\mathrm{km}^{2}$, respectively, over the past 300 years; the corresponding values for China are about $89.73 \times 10^{4} \mathrm{~km}^{2}$ and $40.00 \times 10^{4} \mathrm{~km}^{2}$, respectively. In terms of the spatial patterns, the expansion in cropland in China mainly occurred in the border areas (including the northeast, southwest and Inner Mongolia) and in the hilly areas. Cropland expansion in the USA mainly occurred in the mid-west regions. In China, population growth is the most important driving factor in changes in land use and land cover, whereas in the USA, government policy plays the most significant role.
\end{abstract}

Keywords: land use/cover change; historical comparisons; past 300 years; China; the USA

\section{Introduction}

Changes in land use and land cover have important effects on the Earth's climate system, and much attention has been paid to these studies by scientists in the field of global environmental change (Foley et al., 2005; Pielke, 2005; Pitman et al., 2011). As a core research area in global change, historical land use and land cover changes (LUCC) are important in

Received: 2015-03-06 Accepted: 2015-04-01

Foundation: National Natural Science Foundation of China, No.41271227; China Global Change Research Program, No.2010CB950901

Author: He Fanneng, Professor, specialized in historical geography. E-mail: hefn@igsnrr.ac.cn

"Corresponding author: Li Shicheng, PhD Candidate, specialized in land use/cover change. E-mail: lisc.10s@igsnrr.ac.cn 
studying the effects of human activities on climate and the ecological system over a long time-scale (Thompson, 2000; Ellis et al., 2013; He et al., 2014).

In recent years, many studies related to historical LUCC have been carried out, especially for the past 300 years (Yang et al., 2014; He et al., 2015). In terms of regional scale, Waisanen and Bliss (2002) developed a data set of population and agricultural land for the conterminous USA at the county level from 1790 to 1997. Using Chinese historical taxes-cropland area records from historical archives such as Collections of Historical Governmental Archives and General Chorography of Shengjing, Ge et al. (2008) estimated changes in land use and their relation with carbon cycles over the past 300 years in China. He et al. (2008) estimated the changes in the area of provincial forest in China from 1700 to 1998 using historical records and modern inventories. Based on satellite data and historical archives, Tian et al. (2014) reconstructed land use (including croplands, forest, grassland/shrubland and built-up areas) and its transformations in India from 1880 to 2010. Leite et al. (2012) reported the first spatially explicit reconstruction of historical land use patterns in Brazil, including both cropland and pastureland, from 1940 to 1995.

Numerous efforts have been made on the global scale to reconstruct historical LUCC. The History Database of the Global Environment (HYDE) was created by the Netherlands Environmental Assessment Agency, and has been updated several times (Klein Goldewijk et al., 2011). The global historical cropland data set SAGE was published using a hindcast modeling technique (Ramankutty and Foley, 1999). Based on the SAGE data set and a country-based method for AD 800 to 1700 using population data as a proxy for agricultural activity, Pongratz et al. (2008) reconstructed agricultural areas for 800-1992, while Kaplan et al. (2011) simulated anthropogenic deforestation based on a non-linear relationship between population density and land use. The Global Land Use Model has been used to produce historical global estimates of $1^{\circ}$ fractional land use patterns and underlying land use transitions annually for the period 1700-2000 (Hurtt et al., 2006). These authors also developed a new "harmonized" data set of global gridded land use change scenarios for the period 1500-2100 (Hurtt et al., 2011).

However, most studies have concentrated on the reconstruction of historical LUCC and there are few comparative researches of historical LUCC between different regions or countries. Only a few comparative studies among different data sets for the same region have been reported (Ramankutty et al., 2010; He et al., 2013; Zhang et al., 2013). The LUCC research project launched by IGBP (International Geosphere-Biosphere Programme) and IHDP (International Human Dimensions Programme) in the 1990s not only made the topic of how human activities have changed land cover over the past 300 years important, but also aimed at comparative studies between different regions (Turner et al., 1995). Comparative studies can help us to understand the processes and mechanisms of LUCC for different backgrounds, allowing us to adjust our land use activities and adapt to global climate change for sustainable development.

The aim of this study is to compare the processes of land use change and its driving forces between China's mainland and the conterminous USA to reveal differences in land use at large scales against different backgrounds. 


\section{Study area and materials}

\subsection{Study area}

The study area of this comparative work is China's mainland (excluding Hong Kong, Macao and Taiwan) and the conterminous USA (excluding Alaska and Hawaii).

China, located in East Asia, is one of the largest developing countries in the world. It lies between latitudes $18^{\circ}$ and $54^{\circ} \mathrm{N}$ and longitudes $73^{\circ}$ and $135^{\circ} \mathrm{E}$. China's landscapes vary significantly across its vast width. In the east, there are extensive and densely populated alluvial plains, whereas the mid-west is dominated by hills and mountain ranges. Plains and basins account for one-third of the land area, and the hills and mountains account for two-thirds of the land area. China's climate is mainly dominated by dry seasons and wet monsoon seasons, which leads to pronounced temperature differences between winter and summer. The major climatic zones are temperate and sub-tropical zone. China has a long agricultural history and is one of the world's most populous countries, with a population of over 1.35 billion and the per capita land resources of Chinese are lower.

The USA is one of the largest developed countries in the world. The contiguous USA is located on the east coast of the Pacific Ocean and forms the central part of the North American continent. It lies between latitudes $25^{\circ}$ and $50^{\circ} \mathrm{N}$ and longitudes $65^{\circ}$ and $135^{\circ} \mathrm{W}$. The land area of the contiguous USA is approximately $7,663,941 \mathrm{~km}^{2}$, half of which is plain. It includes most types of climate and has similar climate zones to China. As a young country, the USA has a short history of land cultivation compared with China. After independence in 1776 and the industrial revolution beginning in the 1760s, the land resources of the USA were substantially cultivated. The population of the USA is only about one-fourth that of China, and the amount of land resources available per capita is more than that for the Chinese.

\subsection{Data sources}

Table 1 lists the data sources used in this study. For China, the area of cropland over the past 300 years is based on that reported by Li et al. (2015). Based on the work of Ye et al. (2009), Ge et al. (2004) and some revision and estimation work of their own, Li et al. (2015) reconstructed the cropland area of China's mainland for 1661-1996. The amount of forest area over the past 300 years was based on the work of He et al. (2008). The population data for the period of the Qing Dynasty was taken from Cao and Ge (2001) and data for the period since the establishment of the People's Republic of China was taken from the National Bureau of Statistics of China $(1988,2001)$. All these land use/cover and population data were estimated based on historical documents/events in China and thus have a high level of

Table 1 Sources of land use/cover and population data of China and the USA over the past 300 years

\begin{tabular}{cllll}
\hline Country & \multicolumn{1}{c}{ Cropland } & \multicolumn{1}{c}{ Forest } & \multicolumn{1}{c}{ Grassland } & \multicolumn{1}{c}{ Population } \\
\hline China & Li et al. (2015) & He et al. (2008) & $\begin{array}{l}\text { SAGE (Ramankutty } \\
\text { and Foley, 1999) }\end{array}$ & $\begin{array}{l}\text { Cao and Ge (2001), } \\
\text { NBSC (1988, 2001) }\end{array}$ \\
\multirow{2}{*}{ USA } & $\begin{array}{l}\text { HYDE3.1 (Klein } \\
\text { Goldewijk } \text { et al., 2011) }\end{array}$ & $\begin{array}{l}\text { SAGE (Ramankutty } \\
\text { and Foley, 1999) }\end{array}$ & $\begin{array}{l}\text { SAGE (Ramankutty } \\
\text { and Foley, 1999) }\end{array}$ & $\begin{array}{l}\text { HYDE3.1 (Klein } \\
\text { Goldewijk et al., 2010) }\end{array}$ \\
\hline
\end{tabular}

NBSC: National Bureau of Statistics of China 
confidence. The area of grassland was taken from Ramankutty and Foley (1999). There are no available grassland data covering the past 300 years from Chinese researchers. All the data were converted into fractional format by dividing by the total land area of China's mainland, approximately $956.38 \times 10^{4} \mathrm{~km}^{2}$ (http://www.gov.cn/guoqing/).

In terms of the conterminous USA, the cropland area data were available from the HYDE3.1 data set (Klein Goldewijk et al., 2011), the SAGE data set (Ramankutty, 2011) and Waisanen and Bliss (2002). A comparison of the data showed that the cropland areas of the USA in the three data sets were similar, but the HYDE3.1 data set covers a longer time-scale and has a higher spatial resolution, so it was adopted for use in this study. The population data for the USA were available in the HYDE3.1 data set (Klein Goldewijk et al., 2010) and from Waisanen and Bliss (2002). The population data of the HYDE3.1 data set and the data of Waisanen and Bliss (2002) were similar, but the HYDE3.1 data set covers a longer time-scale. Therefore, the population data from the HYDE3.1 data set for the past 300 years were used in this study. Data for the forest area of the USA for the past 300 years were available from Clawson (1979) and the SAGE data set (Ramankutty and Foley, 1999). However, Clawson (1979) did not consider the changes in territorial boundaries over time and therefore overestimated the regrowth of forest in the second half of the 20th century (Ramankutty et al., 2010). We therefore used the SAGE data set for the area of forest. The grassland area data of Ramankutty and Foley (1999) were used as these were the only available data for grassland over the past 300 years. All these land use/cover data were given in units of $\mathrm{km}^{2}$. They were also converted into fractional format by dividing by the land area of the conterminous USA (approximately $766.39 \times 10^{4} \mathrm{~km}^{2}$ ) (http://en.wikipedia.org/ wiki/ Contiguous_United_States).

\section{Results}

The comparison results are presented to show two aspects: (1) the overall changes in the area with respect to cropland, forest and grassland; and (2) the changes in the spatial pattern of cropland over the past 300 years.

\subsection{Overall changes in land use/cover}

\subsubsection{Cropland}

Figure 1 illustrates the change in the area of cropland and the land reclamation ratio for China and the USA. Over the past 300 years, the area of cropland in both China and the USA showed an increasing trend overall. The cropland area of China increased from $55.52 \times 10^{4} \mathrm{~km}^{2}$ in 1661 to its maximum of $134.98 \times 10^{4} \mathrm{~km}^{2}$ in the $1980 \mathrm{~s}$, an increase of about $79.46 \times 10^{4} \mathrm{~km}^{2}$ over 320 years. The land reclamation ratio increased from $5.81 \%$ in 1661 to $14.11 \%$ in the $1980 \mathrm{~s}$. For the USA, the cropland area increased from $0.63 \times 10^{4} \mathrm{~km}^{2}$ in 1700 to its maximum of $191.50 \times 10^{4} \mathrm{~km}^{2}$ in 1950 , an increase of about $190.87 \times 10^{4} \mathrm{~km}^{2}$ over 250 years. The annual increase in the area of cropland was about $0.76 \times 10^{4} \mathrm{~km}^{2}$, which was three times that of China. The land reclamation ratio in the USA increased from $<0.10 \%$ in 1700 to $24.99 \%$ in 1950 , about $10.88 \%$ greater than the ratio in China in the $1980 \mathrm{~s}$. In conclusion, although the area of cropland in both China and the USA showed an increasing trend over the past 300 years, the increase in the amount of cropland area in the USA was 
much greater than that in China. It only took about 200 years for the USA to cultivate its land rapidly and to exceed the area of cropland in China. The USA then became the largest agricultural country in the world.
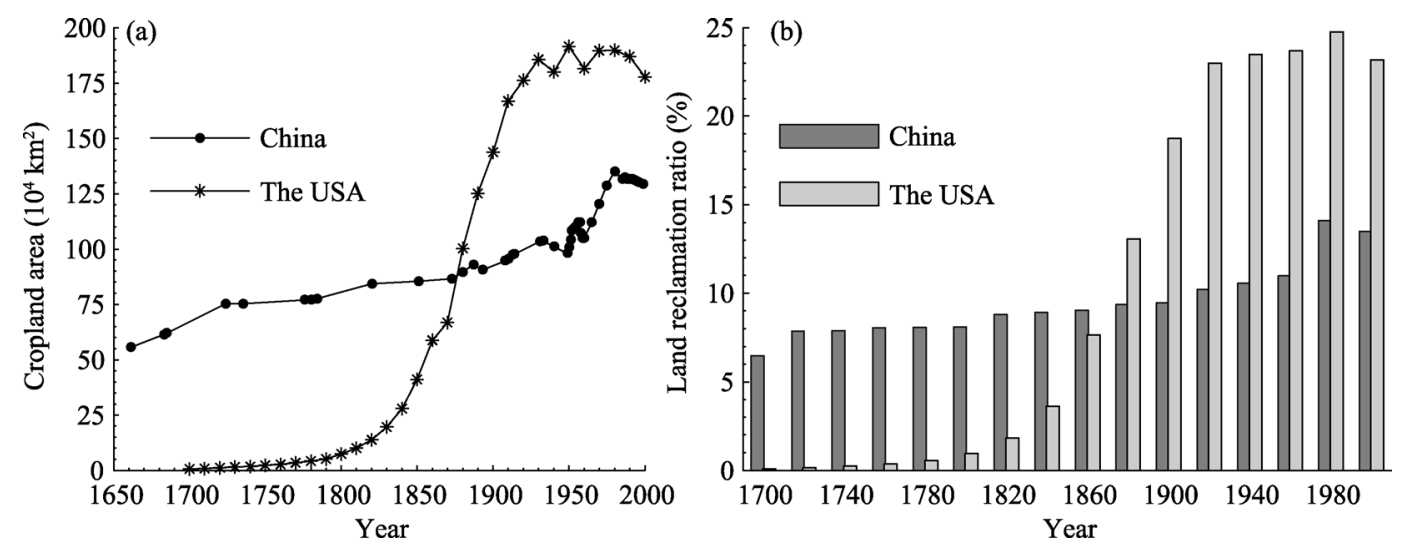

Figure 1 Cropland area (a) and land reclamation ratio (b) in China and the USA over the past 300 years

The land reclamation process in both China and the USA can be divided into three stages (Table 2). For China, the three stages were a rapid growth stage from 1661 to 1724 , a slow growth stage from 1724 to 1873 and a rapid growth with fluctuations stage from 1873 to 2000. The annual growth rates (AGRs) for the three stages were $0.48 \%, 0.09 \%$ and $0.31 \%$, respectively. For the USA, the three stages were a slow growth stage from 1700 to 1800 , a rapid growth stage from 1800 to 1930 and a stable growth stage with fluctuations from 1930 to 2000. In the first stage in the USA, the AGR was $10.61 \%$. After that, the area of cropland increased rapidly and dramatically under the influence of policies related to the development of the mid-western USA. The area of cropland increased from $7.34 \times 10^{4} \mathrm{~km}^{2}$ in 1800 to $185.64 \times 10^{4} \mathrm{~km}^{2}$ in 1930 , and the AGR for that stage was $24.31 \%$. After the $1930 \mathrm{~s}$, land cultivation in the USA became stable, with small fluctuations, and the area of cropland varied between $177.72 \times 10^{4}$ and $191.50 \times 10^{4} \mathrm{~km}^{2}$ as a result of land protection decrees and emerging environmental problems.

Table 2 Characteristics of land cultivation for different stages in China and the USA

\begin{tabular}{|c|c|c|c|}
\hline \multicolumn{2}{|l|}{ China } & \multicolumn{2}{|l|}{ USA } \\
\hline Stage & $\begin{array}{c}\text { Annual growth } \\
\text { rate }(\%)\end{array}$ & Stage & $\begin{array}{l}\text { Annual growth } \\
\text { rate }(\%)\end{array}$ \\
\hline Rapid growth (1661-1724) & 0.48 & Slow growth (1700-1800) & 10.61 \\
\hline Slow growth (1724-1873) & 0.09 & Rapid growth (1800-1930) & 24.31 \\
\hline $\begin{array}{l}\text { Rapid growth with fluctuations } \\
(1873-2000)\end{array}$ & 0.31 & $\begin{array}{l}\text { Stable with small fluctuations } \\
(1930-2000)\end{array}$ & -0.06 \\
\hline
\end{tabular}

\subsubsection{Forest and grassland}

One consequence of land reclamation is the shrinkage of forest and grassland (Figure 2).

Historical documents show that China had extensive forests covering 49.6-64\% of the land area in the pre-agricultural period (Ma et al., 1997; Fan and Dong, 2001). As the population increased over the centuries, deforestation occurred over a wide area. Over the past 
300 years, the area of forest in China decreased from 1700 to the 1960s, and then recovered gradually from the $1960 \mathrm{~s}$ to 1998 . Overall, the area of forest decreased from $248.56 \times 10^{4}$ $\mathrm{km}^{2}$ in 1700 to $158.83 \times 10^{4} \mathrm{~km}^{2}$ in 1998 (Figure 2a), and the forest coverage decreased from $25.90 \%$ to $13.35 \%$ (Figure 2c). From 1700 to the 1960 s, the forest area decreased by about $163.15 \times 10^{4} \mathrm{~km}^{2}$, and the forest coverage decreased by about $16.65 \%$. From the 1960 s to 1998 , the forest area increased by about $73.42 \times 10^{4} \mathrm{~km}^{2}$, and the forest coverage increased from $8.90 \%$ in 1962 to $16.55 \%$ in 1998 .

(a)
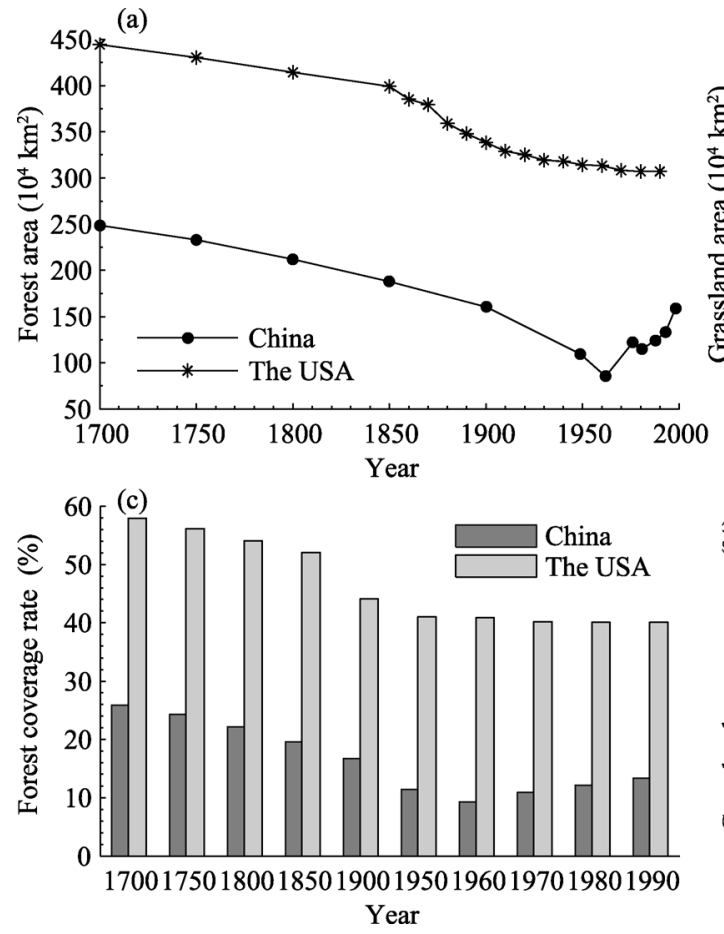

(b)
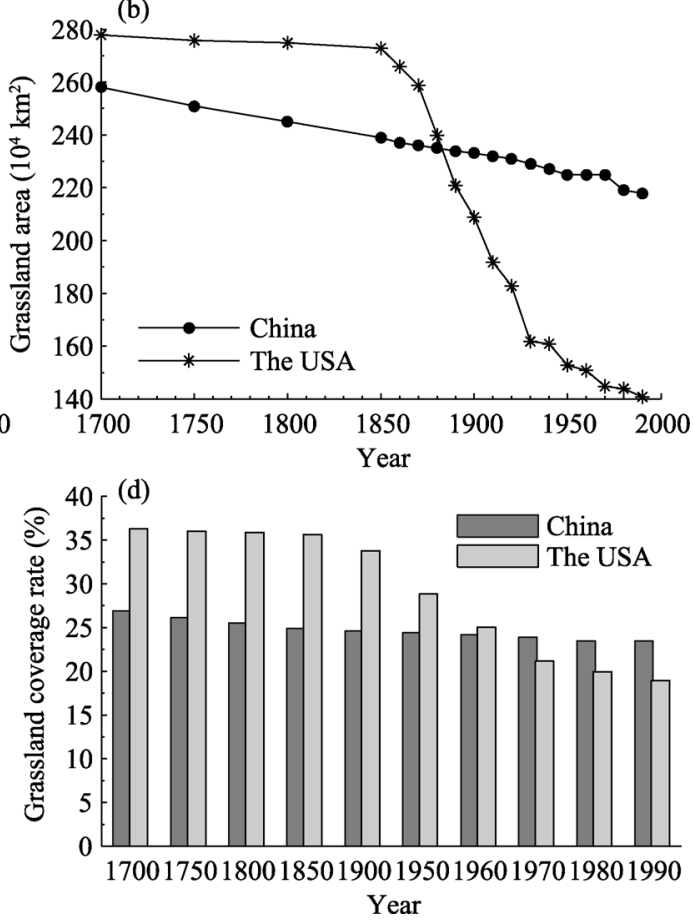

Figure 2 Forest and grassland areas and their coverage rates in China and the USA over the past 300 years

In the USA, the total area of forest in 1700 was $444.18 \times 10^{4} \mathrm{~km}^{2}$, accounting for $57.96 \%$ of the land area of the contiguous USA. Under the influence of the Westward Movement and the implementation of policies related to deforestation, such as the Homestead Act 1862, the area of forest decreased continuously from 1700 to the mid-1900s and then stabilized in the second half of the 20th century (Figure 2a). Over the past 300 years, the area of forest decreased by about $136.98 \times 10^{4} \mathrm{~km}^{2}$, which was roughly the same as the decrease in China from 1700 to the 1960 s. The forest coverage rate decreased by about $17.87 \%$. In 1990 , the forest coverage rate in the USA was $40.09 \%$, obviously greater than that in China. The period of the most rapid decrease in the USA was 1850-1950, during which time, the forested area decreased by $84.98 \times 10^{4} \mathrm{~km}^{2}$ and the forest coverage rate decreased from $52.09 \%$ to $40.09 \%$.

Figures $2 \mathrm{~b}$ and $2 \mathrm{~d}$ show the area of grassland and the trend in the change in grassland coverage rate over the past 300 years for China and the USA. The grassland area decreased gradually in both China and the USA, as did the grassland coverage rate. For China, the grassland area decreased from $258.00 \times 10^{4} \mathrm{~km}^{2}$ in 1700 to $218.00 \times 10^{4} \mathrm{~km}^{2}$ in 1990 , and the 
grassland coverage rate decreased by about $4.17 \%$. For the USA, the grassland area decreased from $277.84 \times 10^{4} \mathrm{~km}^{2}$ in 1700 to $140.86 \times 10^{4} \mathrm{~km}^{2}$ in 1990 , and the grassland coverage rate decreased by about $17.87 \%$. From 1850 to 1990 , the area of grassland in the USA decreased by about $131.98 \times 10^{4} \mathrm{~km}^{2}$, and the grassland coverage rate decreased by about $17.22 \%$, which was approximately eight times the value for China in the same period. In 1700 , the grassland coverage rate of the USA was greater by about $9.37 \%$ than that of China, whereas in 2000 , the coverage rate in the USA was $4.34 \%$ lower than that in China.

\subsection{Spatial patterns of cropland}

We were limited in our ability to compare the spatial patterns of crop cover in China and the USA as a result of the unavailability of spatially explicit data for forests and grasslands over the past 300 years.

Figure 3 illustrates the crop cover of China for 1724, 1784, 1820, 1873, 1933 and 1990 at a resolution of $10 \mathrm{~km}$ (Li et al., 2015). Figure 4 illustrates the crop cover of the USA for $1720,1780,1820,1880,1930$ and 1990 at $5 \min$ (about $10 \mathrm{~km}$ at the equator) resolution (Klein Goldewijk et al., 2011). It can be seen that there are large differences in the changes in crop cover between China and the USA. In general, over the past 300 years, cropland in China expanded toward the frontier, hilly and mountainous regions around the traditional cultivated regions, whereas the cropland of the USA expanded mainly from the east to the mid-west.

In the 18 th century (Figures $3 a, 3 b, 4 a$ and $4 b$ ), the cultivated regions in both China and the USA were mainly distributed in the plains, which were suitable for crop growth, but the intensity of land use and cropland scope for China were obviously larger than those of the USA. The land reclamation ratio for the North China Plain, the mid-lower reaches of the Yangtze River Plains and the Guanzhong Basin were larger than $70 \%$ in some regions (Figures $3 \mathrm{a}$ and $3 \mathrm{~b}$ ). For the USA, the cropland was mainly distributed in the plains of the eastern Atlantic coast before 1776, i.e. the early European colonial district, including Pennsylvania, New Jersey and Virginia (Figures $4 \mathrm{a}$ and $4 \mathrm{~b}$ ).

Subsequently, in the 19 th and early 20 th century (Figures $3 c, 3 d, 4 c, 4 d$ and $4 \mathrm{e}$ ), under the influence of an increasing population, the cropland expanded toward the frontier, hilly and mountainous regions in China, including the Liaohe River Plain, the Sichuan Basin and the Yunnan-Guizhou Plateau (Figures $3 \mathrm{c}$ and 3d). The intensity of land use also increased in these regions. In terms of the USA, even before the American Civil War (1861-1865), the areas of cultivation crossed the Appalachian Mountains and the cropland expanded to the Great Lakes Plains and the Gulf Plains regions with the influx of immigrants (Figure 4c). At the end of the 19th century and the early 20th century, land use intensified in the mid-east regions, and a large number of immigrants passed through the Mississippi region to cultivate land in the Rocky Mountains and the far western regions. Under cultivation by millions of pioneers, the Great Plains became the most important agricultural base of the USA after the Civil War (Figures 4d and 4e).

In the 20th century (Figures 3e, 3f, 4e and 4f), the cultivation of land in both China and the USA stabilized and the intensity of land use decreased slightly. For China, apart from increases in the area of cropland in the northeast, southwest, northwest and the eastern part of Inner Mongolia, decreases in cropland area in the eastern provinces were seen (Figure 3f). 


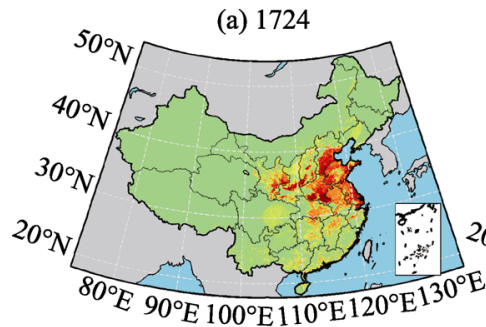

(d) 1873
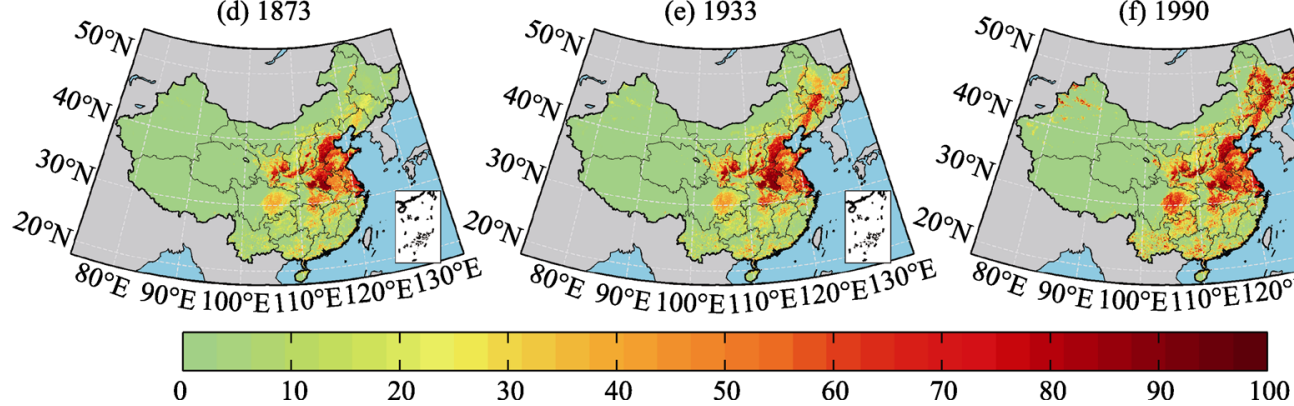

Figure 3 Crop cover of China for 1724, 1784, 1820, 1873, 1933 and 1990 at $10 \mathrm{~km}$ resolution (percentage of grid cell)
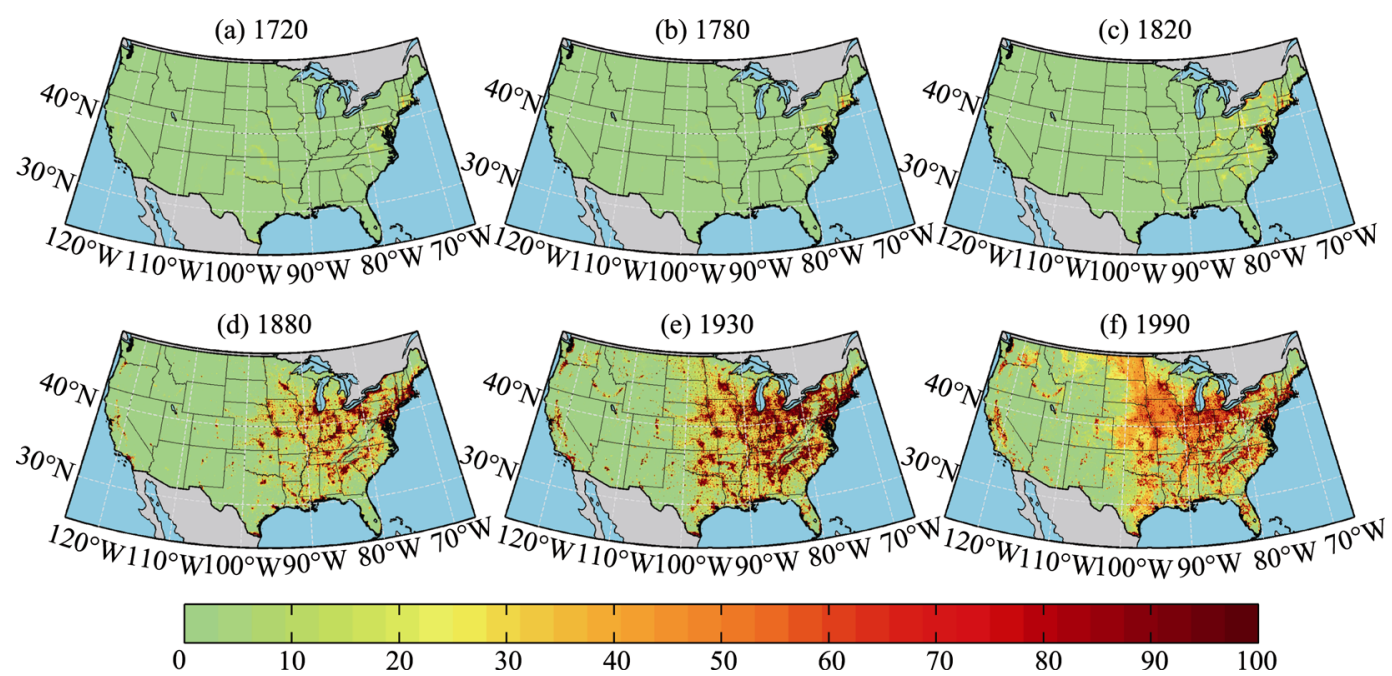

Figure 4 Crop cover of the USA for 1720, 1780, 1820, 1880, 1930 and 1990 at 5 arc minutes (about $10 \mathrm{~km}$ at the equator) resolution (percentage of grid cell)

In terms of the USA, because of the effects of the dust bowl in the 1930s, the government introduced a serious of policies and took measures to protect forests. As a result, the land cultivation process stabilized and the land reclamation ratio decreased slightly (Figure 4f).

\section{Comparative analysis of driving forces}

\subsection{Population}

Cropland is the material basis of human existence. In traditional agricultural societies, an increase in population is the most direct factor driving land use and land cover change. Fig- 
ure 5a illustrates that the population of China increased dramatically from 0.17 billion in 1685 to 0.43 billion in 1850 and to 1.30 billion in 2000. More people need more food, which means that more cropland is required. In Emperor Qianlong's reign in the Qing Dynasty (1736-1796), the government was concerned about this issue and took many measures to cultivate as much land as possible and to improve the intensity of land use (which can be seen from many historical documents). Even so, the per capita cropland area has decreased over the past 300 years from $0.37 \times 10^{4} \mathrm{~m}^{2}$ in 1685 to $0.10 \times 10^{4} \mathrm{~m}^{2}$ in 2000 (Figure $5 \mathrm{~b}$ ).
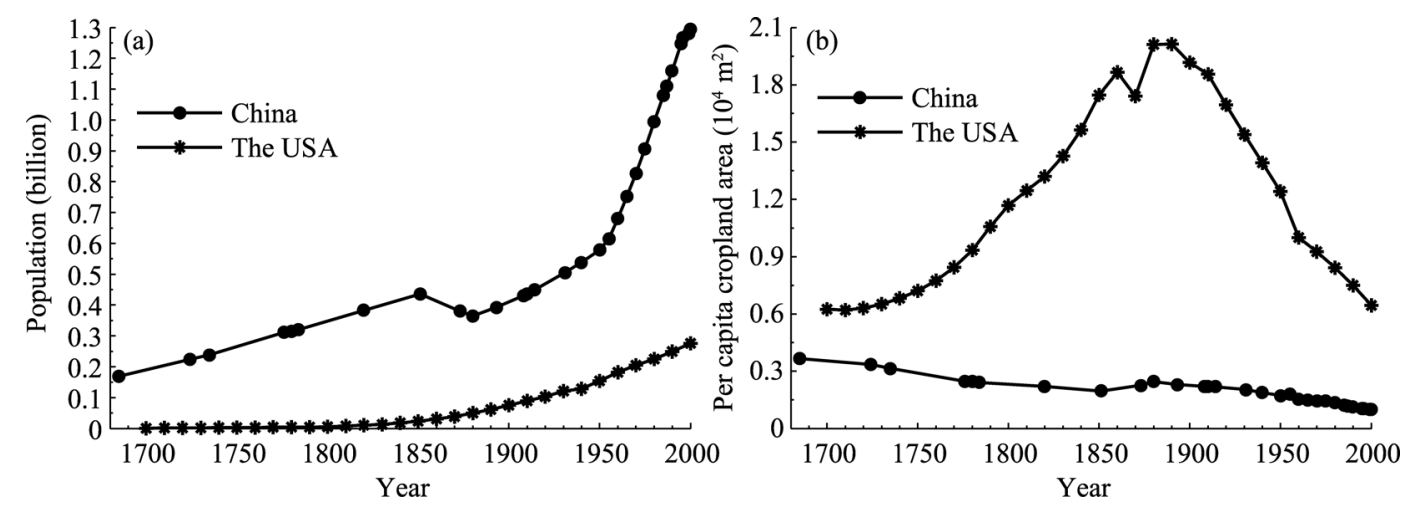

Figure 5 Population (a) and per capita cropland area (b) in China and the USA over the past 300 years

Unlike China, the USA is a large country with many land resources and a relatively sparse population. Its population has increased over the past 300 years from 0.001 billion in 1700 to 0.276 billion in 2000 (Figure 5a), but the increase in population has not caused a decrease in the per capita cropland area because the land area of the USA also increased. To extract more economic benefits from the land, the government took in immigrants from abroad to cultivate the land. More than 5 million immigrants were absorbed into the USA from 1820 to 1860. From 1860 to 1914 , the total number of immigrants in the USA was 27 million. The population west of the Appalachian Mountains increased rapidly from 638,000 in 1800 to 3 million in 1820; 20 years later, the population increased to 8.1 million. In 1860, the population in the west of the USA accounted for $49 \%$ of the total population of the country (Deng, 1990). As a result of this immigration, the US government dramatically boosted land reclamation. In terms of the per capita cropland area (Figure $5 \mathrm{~b}$ ), even the minimum value of the past 300 years was greater than $0.60 \times 10^{4} \mathrm{~m}^{2}$. The value increased gradually before 1890 and then decreased gradually. In 1700 , the value was $0.62 \times 10^{4} \mathrm{~m}^{2}$, whereas in 1890 , it was $2.01 \times 10^{4} \mathrm{~m}^{2}$ and in 2000 , it was $0.65 \times 10^{4} \mathrm{~m}^{2}$.

\subsection{Policies of land reclamation}

Land reclamation is highly correlated with the policies carried out by governments. For China, in the Qing Dynasty (1644-1911), the government implemented many policies to encourage land reclamation. After Emperor Qianlong's reign (1736-1796) in the Qing Dynasty, as the population increased rapidly and natural disasters occurred, the government settled refugees from northern China, who were suffering from famine, floods and drought, into northeast China and Inner Mongolia. They farmed 500,000 ha of land in northeast China and tens of thousands of hectares of land in Inner Mongolia by the 1780s. The culti- 
vation of lands in Xinjiang by native soldiers and farmers was another policy implemented by the Qing government, which also expanded the distribution of cropland in the border regions of China. After 1949, when the People's Republic of China was founded, the government paid much attention to agricultural development. As a result, the area of cropland increased continually from the 1960s to the 1980s (Ge et al., 2008). However, after the 1980s, as various environmental crises occurred, the government took action to protect the environment, including the Natural Forest Conservation Program and the Grain to Green Program (Xu et al., 2006), resulting in a decrease in the area of cropland. Rapid urbanization after the 1980s also contributed to the loss of cropland area.

For the USA, in the early days of its establishment, the government also implemented some policies to encourage land cultivation, including the Land Ordinance of 1785, which provided a mechanism for selling land. Land was systematically surveyed into square townships, and each of these townships was sub-divided into 36 sections of one square mile (2.59 $\mathrm{km}^{2}$ ) or 640 acres. These sections could be sold for one dollar. The Land Ordinance of 1785 laid the foundations of land policy until the passage of the Homestead Act in 1862. The act gave an applicant ownership of land (usually 160 acres or $0.65 \mathrm{~km}^{2}$ ), typically called a homestead, at little or no cost. Any citizen of the USA willing to settle on and to farm the land for at least five years could file an application to claim a federal land grant (CIRD, 1999). Under the influence of these policies, the area of cultivated land increased rapidly and dramatically, particularly in the western regions of the USA.

However, since the 1930s, as urbanization accelerated and the desertification in the western regions became more serious, policies that aimed to protect the land and environment were introduced and carried out. For example, the Taylor Grazing Act, drafted in 1934 by the US Congress, said that if the land was unsuitable for cultivation, the US President had the right to reclaim the land from the settlers and buyers to control soil erosion. The Soil Protection Act, passed by Congress in 1935, also stated that the farmers had a responsibility to develop devices to protect the land, or to leave it fallow to restore fertility (Platt, 2004). In a similar way to China, the cropland area of the USA decreased slightly with small fluctuations under the influence of these policies.

\subsection{Agricultural technology}

In traditional agricultural societies, to obtain the maximum benefit from the land, people developed agricultural technology gradually, which had significant influences on the patterns of agricultural development in a particular region or country. Because of the large differences in population and natural resources between China and the USA, the pattern of development of their agricultural technology followed different paths, and different agricultural technologies led to different characteristic changes in land use/land cover.

As China has a long history, land such as the plains and basins, which were suitable for crop growing, was widely cultivated, even in ancient times. Therefore, to feed the increasing population, farmers had to increase the production per unit area of land by using multiple cropping and crop rotation technology, rather than by cultivating virgin land because there was little natural land suitable for cultivation. For example, even in the Ming and Qing dynasties (1368-1912), farmers harvested twice a year in the Yangtze River Basin and three times a year in the Pearl River Basin (Tang, 1985). In addition, the mechanization of agri- 
culture was very late in China compared with the USA, and only a few small devices for processing agricultural products were available during this time. This slow development of agricultural technology may explain the slow increase in cropland area and the corresponding slow decrease in grassland and forests in China.

In contrast, the USA had a small population and a very high per capita value for land area. For a very long time, the lack of labor forces was the major factor limiting the development of agriculture. Farmers in the USA had to find ways to cultivate large areas of land with a small population and chose agricultural mechanization. As a result, from 1700 to the $1930 \mathrm{~s}$, the production of each member of the labor force (or the land area cultivated by each individual) increased, which meant that the area of cropland gradually expanded and the areas of forests and grasslands correspondingly decreased gradually (He, 2000).

\section{Concluding remarks}

In this study, we compared the temporal and spatial differences in LUCC over the past 300 years between China and the USA. Major findings of this study are summarized as follows.

(1) Over the past 300 years, the areas of cropland in both China and the USA have shown an increasing trend overall. As a large, traditional agricultural country, China saw its area of cropland increase by about $79.46 \times 10^{4} \mathrm{~km}^{2}$ from 1661 to the $1980 \mathrm{~s}$, and the corresponding land reclamation ratio increased from $5.81 \%$ in 1661 to $14.11 \%$ in the 1980 s. As a young country, the USA began to develop its agriculture late, but its rate of development has been fast. Its area of cropland increased by about $190.87 \times 10^{4} \mathrm{~km}^{2}$ from 1700 to 1950 , and its land reclamation ratio increased from about $0.08 \%$ in 1700 to about $24.99 \%$ in 1950 . It took the USA only about 250 years to cultivate cropland of a much greater area than the amount cultivated in China over millennia, and the USA has become the largest agricultural country in the world.

(2) As a result of the expansion of land reclamation, the area of forest and grassland in both China and the USA has decreased substantially over the past 300 years. For China, the area of forest area decreased by about $89.73 \times 10^{4} \mathrm{~km}^{2}$ and the area of grassland decreased by $40.00 \times 10^{4} \mathrm{~km}^{2}$. For the USA, the area of forest decreased by $136.98 \times 10^{4} \mathrm{~km}^{2}$ and the area of grassland decreased by $136.98 \times 10^{4} \mathrm{~km}^{2}$. Over the past 300 years, deforestation and the degradation of grassland in the USA have been much more dramatic than in China.

(3) In terms of the spatial patterns, the land reclamation processes of China and the USA over the past 300 years are different. In general, the area of cropland in China expanded toward the frontier, hilly and mountainous regions around the traditional plain regions, whereas in the USA, the expansion of cropland mainly occurred from the east to the mid-west under the influence of the Westward Movement.

(4) Government policies, increases in population and advances in agricultural technology have been the major factors affecting the changes in land use/land cover in China and the USA over the past 300 years. Taking the differences in natural resources and the history of development into consideration, population growth has been the most important driving factor in China, whereas government policy has played the most important role in the USA. 


\section{References}

Cao Shuji, Ge Jianxiong, 2001. China Population History (Volume V: Qing Dynasties). Shanghai: Fudan University Press. (in Chinese)

China Institute for Reform and Development (CIRD), 1999. The land legislation and land policies of America. Review of Economic Research, 41: 2-12. (in Chinese)

Clawson M, 1979. Forests in the long sweep of American history. Science, 204(4398): 1168-1174.

Deng Shusheng, 1990. America and Immigration: Past Present Future. Chongqing: Chongqing Publishing Group. (in Chinese)

Ellis E C, Kaplan J O, Fuller D Q et al., 2013. Used planet: A global history. Proceedings of the National Academy of Sciences of the United States of America, 110(20): 7978-7985.

Fan Baomin, Dong Yuan, 2001. A discussion on China's ancient forest coverage. Journal of Beijing Forestry University, 23(4): 60-65. (in Chinese)

Foley J A, DeFries R, Asner G P et al., 2005. Global consequences of land use. Science, 309(5734): 570-574.

Ge Quansheng, Dai Junhu, He Fanneng et al., 2004. Spatiotemporal dynamics of reclamation and cultivation and its driving factors in parts of China during the last three centuries. Progress in Natural Science, 14(7): 605-613.

Ge Quansheng, Dai Junhu, He Fanneng et al., 2008. Land Use Changes and Terrestrial Carbon Budgets in China During the Last 300 Years. Beijing: Science Press. (in Chinese)

He Fanneng, Ge Quansheng, Dai Junhu et al., 2008. Forest change of China in recent 300 years. Journal of Geographical Sciences, 18(1): 59-72.

He Fanneng, Li Shicheng, Zhang Xuezhen et al., 2013. Comparisons of cropland area from multiple datasets over the past 300 years in the traditional cultivated region of China. Journal of Geographical Sciences, 23(6): 978-990.

He Fanneng, Li Shicheng, Zhang Xuezhen, 2015. A spatially explicit reconstruction of forest cover in China over 1700-2000. Global and Planetary Change, 131: 73-81.

He Feng, Vavrus S J, Kutzbach J E et al., 2014. Simulating global and local surface temperature changes due to Holocene anthropogenic land cover change. Geophysical Research Letters, 41(2): 623-631.

He Shunguo, 2000. The History of American Frontier: Research of Development Pattern in West Regions. Beijing: Peking University Press. (in Chinese)

Hurtt G C, Chini L P, Frolking S et al., 2011. Harmonization of land-use scenarios for the period 1500-2100: 600 years of global gridded annual land-use transitions, wood harvest, and resulting secondary lands. Climatic Change, 109(1/2): 117-161.

Hurtt G C, Frolking S, Fearon M G et al., 2006. The underpinnings of land-use history: Three centuries of global gridded land-use transitions, wood-harvest activity, and resulting secondary lands. Global Change Biology, 12(7): 1208-1229.

Kaplan J O, Krumhardt K M, Ellis E C et al., 2011. Holocene carbon emissions as a result of anthropogenic land cover change. Holocene, 21(5): 775-791.

Klein Goldewijk K, Beusen A, Janssen P, 2010. Long-term dynamic modeling of global population and built-up area in a spatially explicit way: HYDE 3.1. Holocene, 20(4): 565-573.

Klein Goldewijk K, Beusen A, van Drecht G et al., 2011. The HYDE 3.1 spatially explicit database of human-induced global land-use change over the past 12,000 years. Global Ecology and Biogeography, 20(1): $73-86$.

Leite C C, Costa M H, Soares-Filho B S et al., 2012. Historical land use change and associated carbon emissions in Brazil from 1940 to 1995. Global Biogeochemical Cycles, 26: GB2011.

Li Shicheng, He Fanneng, Zhang Xuezhen, 2015. A spatially explicit reconstruction of cropland cover in China from 1661 to 1996. Regional Environmental Change, 1-12. doi: 10.1007/s10113-014-0751-4.

Ma Zhongliang, Song Chaoshu, Zhang Qinghua, 1997. The Change of China Forest. Vol. 45. Beijing: China Forestry Publishing House. (in Chinese) 
National Bureau of Statistics of China, 1988. China Population Statistics Yearbook. Beijing: China Statistics Press. (in Chinese)

National Bureau of Statistics of China, 2001. China Population Statistics Yearbook. Beijing: China Statistics Press. (in Chinese)

Pielke R A, 2005. Land use and climate change. Science, 310(5754): 1625-1626.

Pitman A J, Avila F B, Abramowitz G et al., 2011. Importance of background climate in determining impact of land-cover change on regional climate. Nature Climate Change, 1(9): 472-475.

Platt R H, 2004. Land Use and Society: Geography, Law and Public Policy. Washington, DC: Island Press.

Pongratz J, Reick C, Raddatz T et al., 2008. A reconstruction of global agricultural areas and land cover for the last millennium. Global Biogeochemical Cycles, 22(3): GB3018.

Ramankutty N, Foley J A, 1999. Estimating historical changes in global land cover: Croplands from 1700 to 1992. Global Biogeochemical Cycles, 13(4): 997-1027.

Ramankutty N, Heller E, Rhemtulla J, 2010. Prevailing myths about agricultural abandonment and forest regrowth in the United States. Annals of the Association of American Geographers, 100(3): 502-512.

Tang Qiyu, 1985. Agricultural History of China. Beijing: Agriculture Press. (in Chinese)

Thompson R S, 2000. BIOME 300: Understanding the impacts of human activities on land cover over the past 300 years. IGBP Newsletter, 43: 2-3.

Tian Hanqin, Banger Kamaljit, Bo Tao et al., 2014. History of land use in India during 1880-2010: Large-scale land transformations reconstructed from satellite data and historical archives. Global and Planetary Change, 121: 78-88.

Turner B L, Skole D L, Sanderson S et al., 1995. Land-use and Land-cover Change Science/Research Plan, IGBP Report No.35, HDP Report No.7. IGBP of the ICSU and HDP of the ISSC. Stockholm and Geneva.

Waisanen P J, Bliss N B, 2002. Changes in population and agricultural land in conterminous United States counties, 1790 to 1997. Global Biogeochemical Cycles, 16(4): 1137.

$\mathrm{Xu}$ Jintao, Yin Runsheng, Li Zhou et al., 2006. China's ecological rehabilitation: Unprecedented efforts, dramatic impacts, and requisite policies. Ecological Economics, 57(4): 595-607.

Yang Yuanyuan, Zhang Shuwen, Yang Jiuchun et al., 2014. A review of historical reconstruction methods of land use/land cover. Journal of Geographical Sciences, 24(4): 746-766.

Ye Yu, Fang Xiuqi, Ren Yuyu et al., 2009. Cropland cover change in Northeast China during the past 300 years. Science in China Series D - Earth Sciences, 52(8): 1172-1182.

Zhang Xuezhen, He Fanneng, Li Shicheng, 2013. Reconstructed cropland in the mid-eleventh century in the traditional agricultural area of China: Implications of comparisons among datasets. Regional Environmental Change, 13(5): 969-977. 